\title{
Grounds for the establishment of a state-owned resort on the territory of the city of Morshyn, Lviv region, Ukraine
}

\author{
Konstantin Babov ${ }^{1}$, Olena Nikipelova ${ }^{1}$, Olha Sydorenko ${ }^{1}$, Sergey Gushcha ${ }^{1}$, Irina Zabolotna ${ }^{1}$, \\ Walery Zukow ${ }^{2 *}$ \\ ${ }^{1}$ State Institution «Ukrainian Research Institute of Medical Rehabilitation Therapy of Ministry of \\ Health of Ukraine», Lermontovskyi bystreet, 6, Odessa, 65014 Ukraine \\ ${ }^{2}$ Nicolaus Copernicus University, Str. Lwowska 1, Torun, 87-100 Poland, \\ *corresponding author’s e-mail: zukow@umk.pl
}

Received: 31 October 2019 / Accepted: 24 April 2020

\begin{abstract}
For the organization of the resorts are environmentally friendly natural areas of resorts, which have natural therapeutic and recreational resources, which is a powerful potential for the development of medical rehabilitation, treatment, health improvement and medical tourism are used. The creation of resorts requires the presence of a number of components: assessment of the environmental component natural therapeutic resources, sanatorium and health resorts, infrastructure (balneological, mud therapy, pump room with mineral water, etc.) and a professional staff of employees. Depending on the quality and value of natural therapeutic resources, there are distinct state and local resorts. On the territory of the city of Morshyn (Lviv region, Ukraine), almost 150 years ago, the use of mineral water for treatment was applied for the first time. Low anthropogenic impact on the environmental status of Morshyn has been established. During the period of independence of Ukraine, the medical-biological evaluation of the medical brines of the Morshynsky deposit of Bonifaci, Banya and Ninivsky deposits was carried out, which included ecological, geographical, hydro-geological, physico-chemical, microbiological and experimental studies in laboratory animals and clinical trials. Also, the current state of the natural territories and infrastructure of the sanatorium and resort establishments is evaluated, the definition of the natural territories of the city of Morshyn grounded as a resort of state importance. At the same time, one of the main conditions justifying the designation of the territory of Morshyn as a resort of state importance is its definition - as an environmentally friendly destination.
\end{abstract}

Key words: environmental status, natural healing resources, recreation areas, climatic and geographical studies, physical and chemical studies.

\section{Introduction}

Article 2 of the Credo of the European Association of resorts states: "Recognition of the status of resorts, health resorts and health facilities must be held on a state legal basis. This recognition should not be based only on local remedies, it should apply to the whole resort with its specific treatment activities". Further, according to article 11, "local natural healing resources are of fundamental importance for resorts, which should be reflected in the state determination of the status of the resort. The healing resources are not yet a resort themselves, 
health resort or health facility. Despite the provisions of common European law, there are still legal differences in the use of medicines - definition, parameters and legal subordination; these differences are the consequence of different traditions." Other important factors (Art. 12) that make the area a resort, is the availability of resort parks; availability of food, which contributes to the health problems; accessibility for the disabled; appropriate equipment for the use of local medical resources; indications for treatment — based on scientific evidence; the presence of cultural and entertainment programs at the resort. The above positions of the European Association of Resorts were taken into account when assessing the recreational areas of Morshyn, Lviv region (Kredo Evropejs'koi Asociacii Kurortiv, 2011).

The development of the health resort sector in Ukraine received a boost after the adoption of the law of Ukraine "On resorts" (Law of Ukraine "On resorts", 2000). The health resort sector is an important component of the health care system, which provides a range of services for the treatment, medical rehabilitation, prevention of diseases of the population. The basis for the development of the health resort sector is the availability of natural healing resources (NHR). One of the directions of development of resort areas is the announcement of natural areas that meet the requirements of the Law of Ukraine "On resorts", resorts of national or local importance.

The resorts of national importance include natural areas that have a particularly valuable and unique NHR and are used for the treatment, medical rehabilitation and prevention of diseases.

The resorts of local importance are natural areas with common NHR and are used for the treatment, medical rehabilitation and prevention of diseases.

The purpose of the article is an assessment of the current status of the major the natural recreational resources of Morshyn and the development of a list of questions necessary for the scientific substantiation of the definition of the natural territory of Morshyn by a resort of national importance of Ukraine.

\section{Materials and methods}

The object of research is natural healing resources (mineral water, climatic conditions, landscapes, recreational resources, environmental condition). The methods are cartographic, comparative-descriptive, ecological, bibliographic methods of analysis of scientific information, physical-geographical, physical-chemical (Certificate, 2017, GOST 23268.0-91, 1999; Zareba, 1999), statistical, analytical. 


\section{Results and discussion}

One of the directions of development of resort areas is the announcement of natural areas that meet the requirements of the Law of Ukraine "On resorts", resorts of national or local importance. The basis for the development and attractiveness for investment of resort and tourist areas in modern economic conditions is the implementation of measures to provide resorts with the status of state and local importance, depending on the available PCR, meeting the demand of the population for specific types of Spa services and improving their quality and comfort; increase of profitability due to the introduction of medical tourism, Wellness and SPA treatments (Babov \& Nikipelova, 2012; Izha et al., 2016).

Nowadays there are seven resorts of national importance in Ukraine - Khmelnik, Saki, Berdyansk, Mirgorod, Skadovsk, Slavyansk, Kuyalnik and three local - Znamenskoye, Solotvino and Kosov.

Morshyn city of Lviv region is one of the leading places in Ukraine on the availability of favorable climatic conditions, unique natural healing resources for the treatment and recreation of the population. The presence of a base of sanatorium-resort complexes, mineral healing waters, natural objects and complexes with favorable climatic conditions for the treatment, landscape and floral factors is of particular value.

Natural and environmental factors of formation of economic potential of the city play one of the main roles, as they determine the attractiveness of the territory, the safety of stay in it and the ability to attract investment.

There are no enterprises polluting the environment and causing irreparable damage ecology of the region. during this time it was possible to save wood lands.

The ecological component of development of economic potential of the region provides preservation of natural and human resources. The mechanisms of their attraction and use depend on the economic levers of development. Environmental conditions directly affect health, living conditions, work, rest and are a condition for a decent human existence. Availability of land, forest, water, mineral, recreational and other types of resources is the basis for economic development. The social sphere through the building of human and social capital, spiritual and cultural potential of human and social development, the rise of the social sphere, the harmonization of social relations has a positive impact on both the economic and environmental spheres (Mashika, 2016).

The enumerated ecological components of economic potential development are being implemented at the resort of Morshyn. First, due to the careful attitude, one of the main 
natural resources of the region - woodlands - has been preserved. Secondly, the absence of industrial enterprises, which is an absolute threat to the environment and ecological status and the concentration of public policy for many years towards the development of the region as a resort destination, is important. This is largely due to the climate and geographical conditions of the Morshyn resort.

Morshyn natural are a is located in the Northeast part of Lvivska oblast. It extends to the Northe as to the river Berezhnytsya to the border with the Ivano-Frankivsk oblast (Fig. 1). Scheme of reliable public transport connection of Morshyn resort with nearby cities is presented on Figure 2.

\section{Morshyn}

Figure 1. Location of Morshyn natural area. Google Maps https://www.google.pl/maps/@48.3680715,30.4777377,6z?hl=en 


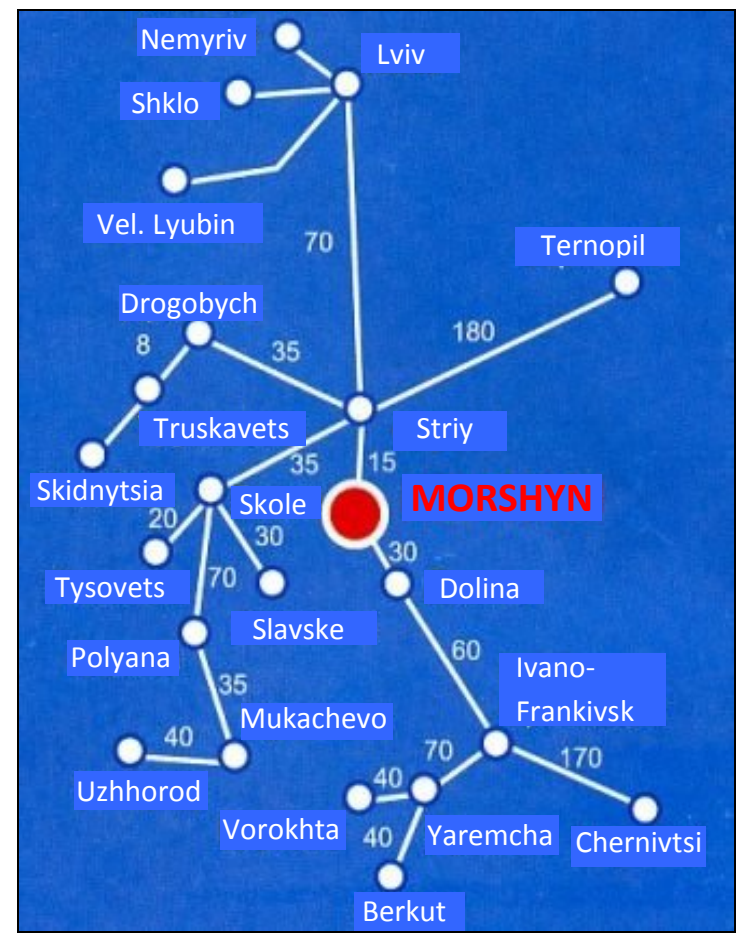

Figure 2. Scheme of public transport connection with Morshyn resort. Numbers denote distances in $\mathrm{km}$

The main rivers that drain this area and quite deeply dissected surface are Svicha and the Berezhnytsya. Areas of high-layer, covered with sod-medium-and strongly podzolic surface soils, which occupy up to $52 \%$ of the territory are dominated in the landscape structure of the Morshyn Natural area. Only the Northern part of this area, adjacent to the Dniester, is expressed by areas of low terraces with sod podzolic and meadow soils, which cover $27 \%$ of the area of all lands (Gerenchuk, 1981).

According to the climatic and geographical characteristics of the resort Morshyn is located in the Carpathian foothills at an altitude of $340 \mathrm{~m}$ above sea level, in a continental climate zone with a relatively mild winter, long wet spring, mild summer, dry (in the first half) autumn. The average annual temperature in Morshyn is $+7.6^{\circ} \mathrm{C}$, the heat (up to $+30^{\circ} \mathrm{C}$ ) in July - August, the coldest (to $-25^{\circ} \mathrm{C}$ ) - in January - February. The warm period lasts from May to October, the cold - from November to March. Number of days with sudden temperature fluctuation (more than $5^{\circ} \mathrm{C}$ ) $-10 \%$, clear days $-28 \%$, cloudy $-27 \%$ of the total number of days in the year is observed. The greatest number of clear days is observed in the warm period of the year, which is important for heliotherapy, the effect of which on the body mainly depends on the intensity of ultraviolet radiation (UR). 
The territory of Morshyn resort belongs to the zone with a small period of UR "hunger strike" - in winter (up to 2.5 months) and strong biological activity in the warm season (more than 5 months). The most intense UR in the area of Morshyn resort is in July. A significant part of it is scattered radiation, so sunbathing can be taken in the shade.

Atmospheric pressure in Morshyn is slightly reduced and is equal to an average of 974 $\mathrm{kPa}$ (731 mm Hg). Maximum air pressure - up to $1000 \mathrm{kPa}$ (750 mm Hg) it is observed, as a rule, in autumn (more often in October), the minimum - within $954 \mathrm{kPa}$ (715 mm Hg) early winter. Morshyn is surrounded by hills that are covered with forests, so days with moderate winds are only $14 \%$ per year. Harsh winds are observed in January, mild winds - in AugustSeptember. The mild climate of the resort Morshyn, the absence of sharp fluctuations in temperature, a beautiful area surrounded by forests, clean, fresh air, filled with the smells of herbs, are favorable conditions for the use of climatotherapy in the complex treatment of patients (Atiushkin et al., 2005).

The resort forests of Morshyn include plantations of the Morshyn forestry of the Stryi State Forestry. The territory of Morshyn is promising to create the track. The main forestforming species of the resort Morshyn is oak, beech, fir and white spruce, but the largest area is occupied by oak stands with an admixture of fir, beech, and sometimes spruce. Often there are aspen, ash ordinary, alder sticky, birch hung, etc. The largest areas of forest plantation are occupied by stands of common oak (1582.7 hectares, i.e. $50.4 \%$ of the forested land). More than $77 \%$ of hardwood deciduous trees occupy the area of Morshyn, 9.6\% of coniferous trees, and $13.3 \%$ of forests covered with softwood. The vast majority of coniferous stands are artificially created on the site of oak and beech forests cut down in the pre-war and post-war years. The age structure of stands in the vicinity of Morshyn was formed as a result of longterm economic use of forests - here dominated by medieval plantations and young plants occupying respectively $68.7 \%$ and $22.0 \%$ of the forested land. Coniferous forests are represented only by young growths and medieval plantations. In percentage terms, the highest percentage of ripe and permanent plantations is characteristic of softwood species, $26.5 \%$ of the total number is stands that have reached the ripe age. Birch, black and gray alder are fast breeds that reach stylists up to $60-80$ years. At the same time, forest pathologies are more likely to be used in such forest states. Forests with predominance in the stand of black alder tree grow in their moistened areas and are an important factor in regulating the hydrological regime of the resort territory. Maintaining their stability should be given maximum attention. After 60 years, wilting processes in the birch forests of the birch forest become more active the trees are populated by birch polypore (Piptoporus betulis (Bull. ex Fr.) Karst.) and tinder 
polypore (Fomelis fomentalis (L. ex Fr.) Fr.), which gradually lead to the destruction of the stand (Denejka, 2003). The birch trees need reconstruction to form the stands of more durable rocks.

An important function of resort forests is their climatic therapeutic properties. Reflective influence of natural landscapes has a positive effect on the neuro-psychological state of recreants, most importantly, rest in the forest combines aesthetic action and physical activity, that is, thus tone the activity of biological resources of the human body (Denejka, (2003).

Recreation areas are very popular among tourists. The creation of eco-trails and path is an example of careful attitude to the Spa forests, which contributes to the protection and rational use of forest plantations. Many natural areas are managed to provide two basic ecosystem services:

- Support of biodiversity at the expense of nature (landscape conservation);

- Providing opportunities for rest and recreation (cultural services).

Recreational trails contribute to the achievement of the set, as they provide access to spatially distributive tourist definitions and the simultaneous restriction of their use in special valuable territories. Visitors can view submitted from sensitive and vulnerable areas. On the other hand, traffic that limits routing may lead to a variety of negative environmental effects, which usually include mixed properties of plants and common plants, expansion of stereotypes, development formal (i.e. visitor-created) trails, soil erosion, and muddiness.

Scientific understanding of the relationship between trail impacts and outhere elements is a more effective and sustained management of recreational trails (Tomczyk \& Ewertowski, 2016).

Green ways (Association of Green Routes in Central and Eastern Europe) - identifies three main categories of green routes (Zaręba, 2007):

- Long-distance green routes (Long-distance Green ways);

- Local green routes (Local Green ways);

- Urban green routes (Urban Green ways).

Urban green route is a multifunctional track (for pedestrians, cyclists, rollers, people in wheelchairs, etc.) that runs along the river, stream, abandoned railway line or natural corridor within the city (Park, green area, etc.). The main purpose of urban green track is a safe movement, rest and get acquainted with the sights.

Criteria:

- At least $90 \%$ of the route is compacted surface; 
- The route represents the way for movement by the non-motorized vehicles separated from the road for motor transport;

- The angles of inclination on the route in relation to the horizontal (about 0 or with a slight deviation) allow people with different physical abilities to use the route, including people with disabilities travelling in wheelchairs;

- There is at least one information table (if the route is a loop) or two tables (if the route is linear);

- There is at least one point for rest and / or stop on the route.

The territory of the city of Morshyn is promising for the creation of urban green routes. Near the sanatorium "Marble Palace" is a trail for Nordic walking. There is a scheme with indications and contraindications, which is used by vacationers for the purpose of recovery, and patients - on prescription - in complex rehabilitation treatment on the territory (Fig. 3).

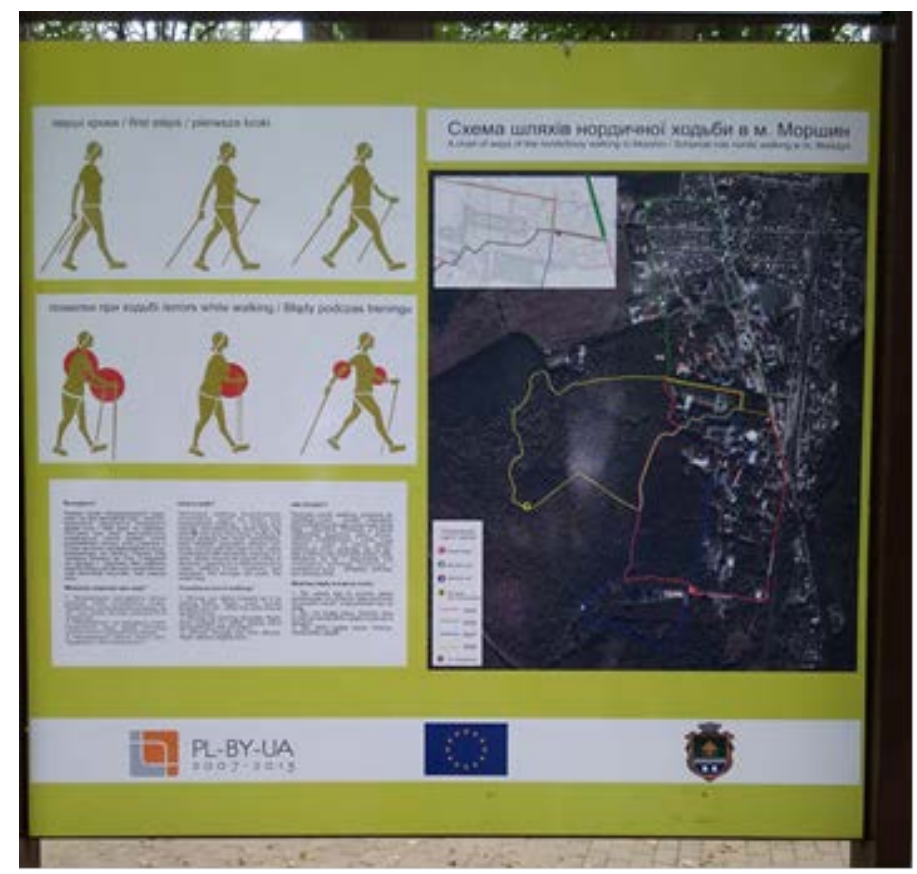

Figure 3. Diagram of the ways Nordic walking in Morshyn

Hydrotherapy is the main type of health improvement and treatment in Morshyn. Hydrotherapy includes, first of all, drinking treatment, which takes place in the equipped pump room of mineral waters, located in the Central part of the old Park (Fig. 4). Mineral waters of different composition and mineralization are given to patients dosed, with specially installed devices called "Jerelo Lux". Pump room of mineral waters provides internal reception of mineral waters to vacationers according to appointment of the doctor. 


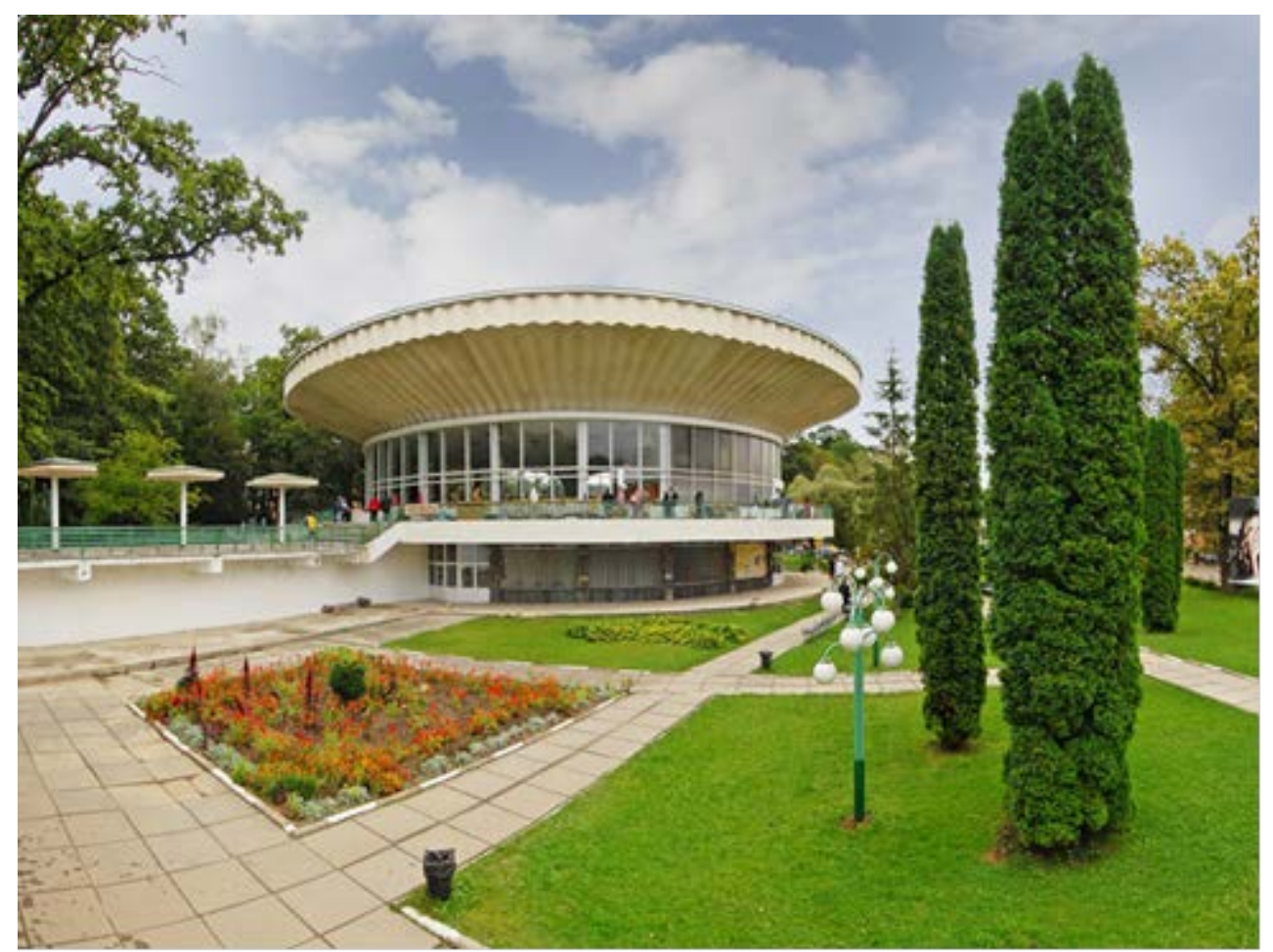

Figure 4. Morshyn Mineral Water Beauvet

Underground water sources No. 4, of the source "Morshynskoe", located in the southern and north-eastern outskirts of the resort Morshyn, its composition is hydrocarbonate, sulfatehydrocarbonate, chloride-hydrocarbonate without specific components and properties. The total mineralization is $0.1-0.4 \mathrm{~g} / \mathrm{l}$.The chemical formula is as follows:

$\mathrm{M}_{0.14-0.15-} \underline{\mathrm{HCO}}_{3} \underline{64-65 \mathrm{Cl} 19-20 \mathrm{SO}_{4}} \underline{14-15}$ Ca 39-40 (Na+K) 38-39 Mg 22-23

This groundwater sources No. 4, is used for breeding water wells No. 1-k, wells No. 2-k and wells No. 3 - Ninovskoye sourse, which is located in the valley of the Zhizhava River, on the outskirts of the village Horishne of Stryi district of the Lviv region.

Brines of the bore No. 1-k are bromine boricsulfate-chloride, magnesium-sodium chloride, sodium slightly acid-neutral, cold, with an iodine content from $0.002 \mathrm{~g} / \mathrm{l}$ to $0.007 \mathrm{~g} / \mathrm{l}$, bromine from $0.09 \mathrm{~g} / \mathrm{l}$ to $100.0 \mathrm{~g} / \mathrm{l}$ and orthoboric acid from $0.020 \mathrm{~g} / \mathrm{l}$ to $0.050 \mathrm{~g} / \mathrm{l}$. The total mineralization from $148.20 \mathrm{~g} / \mathrm{l}$ to $174.50 \mathrm{~g} / \mathrm{l}$, the chemical composition is determined by the following formula: 
No. $1-\mathrm{k}$

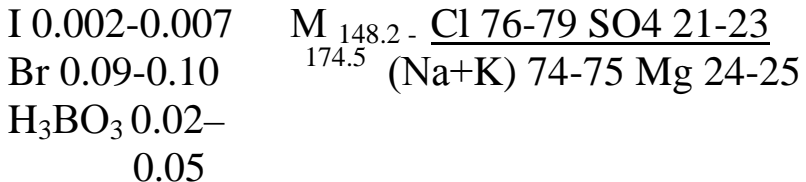

$\mathrm{pH} 6.4$

$\mathrm{T} 11.0^{\circ} \mathrm{C}$

0.05

The total mineralization is brines of the bore No. 2-kareiodine-brominesulfate-chloride, magnesium-sodium chloride, weakly oxidized, cold. Containing orthoboric acid from 0.040 $\mathrm{g} / \mathrm{l}$ to $0.100 \mathrm{~g} / \mathrm{l}$ and iron from $0.007 \mathrm{~g} / \mathrm{l}$ to $0.020 \mathrm{~g} / \mathrm{l}$; containing bromine from $0.180 \mathrm{~g} / \mathrm{l}$ to $0.210 \mathrm{~g} / \mathrm{l}$, and iodine from $0.018 \mathrm{~g} / \mathrm{l}$ to $0.029 \mathrm{~g} / \mathrm{l}$; The total mineralization from $370.98 \mathrm{~g} / \mathrm{l}$ to $389.69 \mathrm{~g} / \mathrm{l}$, the chemical composition is determined by the following formula:

No. 2-k

$$
\begin{aligned}
& \text { I } 0.018-0.029 \\
& \mathrm{Br} 0.18-0.21 \\
& \mathrm{H}_{3} \mathrm{BO}_{3} 0.04-0.10 \\
& \text { Fe } 0.011
\end{aligned}
$$

$$
\mathrm{M}_{389.69} 370.98-\frac{\mathrm{Cl} 74-6 \mathrm{SO} 424-26}{(\mathrm{Na}+\mathrm{K}) 71-72 \mathrm{Mg} 27-28}
$$

Brines of the bore No. 3-k are chloride-sulphate, sulphate sodium, weak-oxide-slightly alkaline, cold, with the content of orthoboric acid from $0.040 \mathrm{~g} / \mathrm{l}$ to $0.110 \mathrm{~g} / \mathrm{l}$. The total mineralization from $121.80 \mathrm{~g} / \mathrm{l}$ to $164.00 \mathrm{~g} / \mathrm{l}$, the chemical composition is determined by the following formula:

No. 3-k

$$
\mathrm{H}_{3} \mathrm{BO}_{3} 0.04
$$

0.11

$$
\mathrm{M}_{121.8}-\frac{\mathrm{SO} 479-84 \mathrm{Cl} 16-20}{(\mathrm{Na}+\mathrm{K}) 83-88 \mathrm{Mg} 10-16}
$$

$\mathrm{pH} 7.2-7.5$

When diluted brine wells No. 1, No. 3 ground water, No. 4 in proportions from $1: 46.32$ to 1: 42.92 mineral diluted waters (MDW) of small mineralization (from $3.0 \mathrm{~g} / \mathrm{l}$ to $4.0 \mathrm{~g} / \mathrm{l}$ ) of sulfate-chloride sodium, magnesium-sodium composition without specific components and properties are received, the chemical composition is determined by the following formula:

$$
\mathrm{M}_{3.0-4.0} \frac{\mathrm{Cl} 50-51 \mathrm{SO}_{4} 46-47}{(\mathrm{Na}+\mathrm{K}) 76-78 \mathrm{Mg} 19-20}
$$

When diluting the brines of the well No. 2-k low-mineralized water source No. 4 in the ratio of $1: 40.90$ to $1: 31.87$, get a diluted $\mathrm{MV}$. 
The obtained MWs are characterized as medium-high-mineralized (from $9.0 \mathrm{~g} / \mathrm{l}$ to $12.0 \mathrm{~g} / \mathrm{l})$ sulfate-chloride magnesium-sodium without specific components and properties. The chemical composition of the MDW corresponds to the following formula:

$$
\mathrm{M}_{9.0-12.0} \frac{\mathrm{Cl} 74-75 \mathrm{SO}_{4} 24-25}{(\mathrm{Na}+\mathrm{K}) 72 \mathrm{Mg} 27}
$$

The experimental researches of the substantiated directions of further clinical trials of MW in Morshyn resorts were made, the results of which were developed recommendations for their practical use in medical practices and received medical (balneological) findings.

According to the (Order of the Ministry of Health of Ukraine), the medical (balneological) conclusion is a unit of complex medical and biological and other special investigations that have the properties of natural resources, including the means related to the use of treatment, medical rehabilitation and disease prevention; a document that regulates the quality of natural resources, as well as the conditional composition of useful and harmful components for human beings (Nakaz MOZ Ukraini vid 02.06.2003 No. 243).

According to the medical (balneological) findings, the medicinal bristle bore No. 2 (source 6) and mineral waters of the South. No. 29-a (source 1) of the Morshynsky deposit can also be used in medical practice for internal application with appropriate dilutions.

The process of breeding, heating and supplying mineral water is fully automated. After the dilution of mineral water to the given concentration (3.5 g/l; $7 \mathrm{~g} / \mathrm{l} ; 14 \mathrm{~g} / \mathrm{l} ; 21 \mathrm{~g} / \mathrm{l})$, using CHIP cards, the dosage of mineral water for $100 \mathrm{mg}, 150 \mathrm{mg}, 200 \mathrm{mg}$ is carried out. After consultations of the doctor-gastroenterologist the course of internal reception of mineral waters is realized.

Important components for the assessment of the sustainable development of the sanatorium and resort facilities in Morshyn are the availability of infrastructure and provision to the clinic-diagnostic and medical facilities of five sanatorium and spa establishments "Morshynkurort", as well as TOV "Helms Master" sanatorium "Marble Palace", TOV " Arcadia Plus ", GI" Sanatorium "Morshynsky" for the rehabilitation of patients mainly gastroenterological profile, with metabolic disorders, with associated diseases of the musculoskeletal system, as well as women with reproductive functions pathologyand pregnant women. It was determined that the volume of treatment with the use of physiotherapy methods meets the requirements of clinical protocols of sanatorium and resort treatment of patients with diseases presented at the Morshyn resort (Babov et al., 2012). 
It should not be forgotten that the purpose of the resorts is not only treatment, but also healing. To date, the low level of health of the population of Ukraine is due in large part to complex socio-economic and environmental crises. But the analysis of the situation that has arisen showed that it is more profitable to spend money on prevention, that is, healing, rather than on the treatment of diseases and their complications.

The purpose of the resorts is not only treatment, but also healing. To date, the low level of health of the population of Ukraine is due in large part to complex socio-economic and environmental crises. But the analysis of the situation that has arisen showed that it is more profitable to spend money on prevention, that is, healing, rather than on the treatment of diseases and their complications (Kiforenko \& Kravchenko, 2014). "Healing" means the restoration and increase of functional reserves and adaptive possibilities of an organism that suffer in the event of the impact of adverse environmental factors (Miheenko, 2013).

Since the first systems that suffer from adverse (stress) influences are the systems of regulation of processes of vital activity, then recovery begins with the restoration of their activities under the influence of $\mathrm{MB}$ or another natural factor. Restoration of regulation provides normalization of the damaged system - CNS and VNS, endocrine and immune organs, organs of the gastrointestinal tract, etc., which increases the adaptability of the whole organism and thus provides for its recovery.

In accordance with the initial orientation at certain levels of the organism's influence, the methods of healing can be divided into two categories:

- specific, directed on a certain physiological system;

- holistic, aimed at general improvement of the person (Semchinskaya, 2009). By the latest methods, the nature of the effect can be attributed to NHR, which are represented by mineral therapeutic waters.

In present conditions of unfavorable ecological situation, the need to restore and improve the adaptive capacity of the body is especially urgent.

Threats that can take advantage of the ecological and geographical situation and quality conditions for recreation at the resort are negative natural physical and geographical processes. Morshyn is one of the few resorts where such processes are virtually unremarkable. The flat area and the absence of harmful mining facilities are a major advantage of the resort. The presence of landfills or landfills in the resort territories clearly does not contribute to a positive environmental situation, so the ways of solid waste management have a significant impact on the formation of the ecological and geographical situation of the resort. Solid household landfills or garbage dumps are absent Near all balneological resorts of Lviv region. 
A household waste management system is operating in Morshyn. Centralized waste removal covers the entire city, as well as primary waste sorting. According to the utilities, 1721.9 tonnes (10.8 thousand $\mathrm{m}^{3}$ ) of MSW are generated annually in Morshyn, which is exported to a landfill near the city of Stryi. However, a slight blockage can occur in the park areas of the resort, as well as in the outskirts of the city, near treatment facilities where natural landfills have been observed. The condition of the economic infrastructure of the resorts is a key factor for the environmental situation and the provision of appropriate social and living conditions. Important is the question of the technical condition of hydraulic structures. In Morshyn, they are in a worn state and require reconstruction, with drinking water losses reaching 209.07 thousand $\mathrm{m}^{3}$ per year, or about $15 \%$ of total consumption.

An important indicator that allows you to assess the ecological and geographical condition of the resort is the area of green space and the availability of one existing resident. In Morshyn, this figure is $114.1 \mathrm{~m}^{2}$ / person, which is higher than the norms stipulated in the Ukrainian legislation - $10 \mathrm{~m}^{2} /$ person. An ecological-stabilizing factor at the resort may be the presence of objects of the nature reserve fund, the existence of which will expand the possibility of providing various recreational services, creating ecological trails or conducting eco-educational activities. The portion of the resort area under the nature reserve fund facilities is only 6.45\%. In Morshyn, the largest resort park in terms of area is a monument of landscape art, which is most used by holidaymakers and locals (Golovatyi, 2015).

The objects that can be attributed to the natural resort and recreational resources of the city of Morshyn are as follows: the presence of a base of sanatorium and resort complexes, mineral sulfate natural medical waters, natural objects and complexes with favorable conditions for treatment of climate conditions, landscape and floristic factors.

In order to recognize Morshyn as a resort of state importance, the following questions need to be addressed:

1. Development of the Strategy for the development of Morshyn as a natural resort area for the period up to 2026, taking into account the elimination of environmental risks.

2. Annual monitoring of the safety and quality of the resort's natural healing resources.

3. Implementation of modern medical and biological assessment of the safety and quality of peat peloids of the Velikolubinsk field and green clay produced by Gafsa Ltd.

the city of Stryi, Lviv region.

4. Improvement of the area around the mineral water pump room.

5. Creation of an information center and system of dissemination of information on the medical and recreational potential of the city. 
6. Ensuring an adequate level of control over the safety of holidaymakers and tourists.

7. Ensuring the formation of a positive image of the city, presentation of the regional recreational and tourist product in the domestic and foreign markets.

\section{Conclusions}

When conducting ecological, climatological, geographical, research, it is revealed that the resort Morshin is a unique ecologically clean natural territory of Ukraine, the short one is surrounded by forests, the healing properties of the climate have a beneficial effect on the recreation.

Taking into account the presence of resort and recreational resources in the city of Morshyn Lviv region (unique chemical composition of mineral healing waters, natural objects and complexes with favorable climate conditions for the treatment, landscape and floral factors), road and rail links to Lviv, Morshyn has grounds for determining the status of the resort of national importance.

\section{References}

Atestat akreditaciï Nacional'nogo agentstva $\mathrm{z}$ akreditacii Ukraini na vidpovidnist' do vimog DSTU ISO/IEC 17025:2006 No. 2N386 vid 04.08.2017 [Accreditation Certificate of the National Accreditation Agency of Ukraine for compliance DSTU ISO/IEC 17025:2006 No. 2N386 vid 04.08.2017], 2017, State standart, ISO/IEC 17025:2006 No. $2 \mathrm{~N}$ 386, Ukraine (in Ukrainian).

Atiushkin V.O., Vladymyrov O.A., Haysak M.O., Galachenko O.O. \& Golubova T.F., 2005, Vikoristannya klimatichnih faktoriv v kompleksi sanatorno-kurortnogo likuvannya [Use of climatic factors in the complex of sanatorium and resort treatment], Fisenko L.I. (Ed.), K., Publisher Kupriyanova, 255 pp. (in Ukrainian).

Babov K.D. \& Nikipelova O.M. (eds), 2012, Kurorti Ukraini derzhavnogo ta miscevogo znachennya [Resorts of Ukraine of state and local importance], Pal'mira, Odesa, 220 pp. (in Ukrainian).

Babov K.D., Nikipelova O.M. \& Tokaria I.M. (eds), 2012, Nove Ninivs'ke rodovishche mineral'nih vod kurortu Morshyn [New Ninivske ancestor of mineral water resort Morshyn], Kolo, 148 pp. (in Ukrainian).

Dejneka A., 2003, Li`sovi` nasadzhennya okrug sani`tarnoyi okhoroni gi`rs`kikh kurorti`v L`vi vshhini [Forests around the sanitary protecting areas of mountain resorts in L'viv region], http://dspace.nbuv.gov.ua/bitstream/handle/123456789/73757/29dejneka.pdf?sequence=1 (in Ukrainian).

Gerenchuk K.I., 1981, Priroda L'vivs'koï oblasti [The nature of the Lviv region], L'viv, Vishcha shkola, 156 pp. (in Ukrainian). https://geoknigi.com/book_view.php?id=650

Golovatyi M.V., 2015, Ekologi`chni zagrozi zbalansovanomu rozvitkovi` bal`neologi'chnogo kurortu Morshin [Environmental threats to the balanced development of the Morshyn spa resort], Fi`zichna geografi ya ta geomorfologi ya 4(80), Part I. (in Ukrainian).

Google Maps. https://www.google.pl/maps/@48.3680715,30.4777377,6z?hl=en 
Izha M.M., Babov K.D. \& Bezverhnyuk T.M. (eds), 2016, Regional'nij turistichnij produkt: proektnij pidhid do zabezpechennya konkurentospromozhnosti [Regional tourist product: design pidhid to be sure to compete], Odesa, ORIDU NADU, $626 \mathrm{pp}$. (in Ukrainian).

Kiforenko S.I., Kravchenko V.V., 2014, Informacionno-tekhnologicheskie aspekty kontrolya i korrekcii fizicheskogo zdorov'ya [Information and technological aspects of monitoring and correction of physical health], Visnik Kiïvs'kogo nacional'nogo universitetu im. T.G. Shevchenka. Kibernetika 1(12): 27-32 (in Ukrainian).

Kredo Evropejs'koi Asociacii Kurortiv (KEAK) [Credo of the European Association of Resorts], 2011,Satz-Studio Schmitt Postfach 1304 D-55276 Oppenheim. http://www.espa-ehv.com-/content/view/176/267/lang.de/ (in Ukrainian).

Mashika G.V., 2016, Prirodno-ekologichni chinniki ta ih rol' u formuvanni gospodars'kogo potencialu Karpats'kogo regionu [Natural-ecological factors and their role in shaping the economic potential of the Carpathian region], Naukovi zapiski Vinnic'kogo derzhavnogo pedagogichnogoUniversitetu imeni Mihajla Kocyubins'kogo. Seriya: Geografiya 28(3-4): 1-199 (in Ukrainian).

Miheenko O.I., 2013, Konkretizaciya sutnosti ponyattya “zdorov’ya” yak metodologichne pidgrunty praktiki ozdorovlennya organizmu lyudini [Concretizing the understanding of "health" as a methodological tool for improving the health of people]. Pedagogika, psihologiya ta mediko-biologichni problemi fizichnogo vihovannya i sportu 2: 42-46 (in Ukrainian).

Pro zatverdzhennya Poryadku zdijsnennya mediko-biologichnoï ocinki yakosti ta cinnosti prirodnih likuval'nih resursiv, viznachennya metodiv ïh vikoristannya [About the established order of medical and biological assessment of the nature of the natural resource resources, according to the method of its copyright], 2003, Nakaz MOZ Ukraini vid 02.06.2003 No. 243 (in Ukrainian). https://zakon.rada.gov.ua/laws/show/z0752-03

Semchinskaya E.I., 2009, Ozdorovlenie kak problema upravleniya zdorov'em [Improvement as a problem of health management]. Kibernetika i vychisl. tekhnika 156: 10-17 (in Ukrainian).

Tomczyk A. \& Ewertowski M., 2016, Recreational trails in the Poprad Landscape Park, Poland: the spatial pattern of trail impacts and use related, environmental, and managerial factors. Journal of Maps 12(5): 1227-1235. https://www.tandfonline.com/doi/pdf/10.1080/17445647.2015.1088751

Vody mineral'nye pit'evye lechebnye, lechebno-stolovye. Pravila priemki i metody otbora prob [Waters mineral drinking medicinal, medical and dining. Acceptance rules and methods of sampling], 1999, GOST 23268.0-91, M. IPK Izd-vo standartov, 4 pp. (in Russian).

Zakon Ukraini "Pro kurorti" [Law of Ukraine "On Resorts"], 2000, No. 2026, III vid. 05.10.2000, (in Ukrainian). https://zakon.rada.gov.ua/laws/show/2026-14

Zareba D. (ed.), 1999, Vody mineral'nye pit'evye lechebnye, lechebno-stolovye. Pravila priemki i metody otbora prob [Waters mineral drinking medicinal, medical and dining. Acceptance rules and methods of sampling]. GOST 23268.0-91 [1992-0701]. M., IPK Izd-vo standartov, 4 pp. (in Russian).

Zaręba D. (ed.), 2007, Zielone szlaki, Praktyczny poradnik [Green ways, Practical handbook]. Fundacja Partnerstwo dla Środowiska, Kraków-Brno (in Polish). 